\title{
Knowledge, attitude, and practice regarding COVID-19 pandemic among medical students of Ernakulam, India
}

\author{
Jacob Davies Kalliath ${ }^{1}$, Anuradha Kizhatil ${ }^{1^{*}}$, Brilly M. Rose ${ }^{1}$, Ann Mary Kuncheria ${ }^{1}$, Alexander John ${ }^{1}$
}

\begin{abstract}
Background: COVID - 19 infection is a serious pandemic the world is now facing. This study aimed to assess the knowledge, attitude, and practice regarding COVID-19 infection among medical students at a private medical college in central Kerala.

Methods: A cross-sectional web-based study was conducted during April-May 2020 in a private medical college in Ernakulam District using the Universal sampling technique. The study tool was a semi-structured validated questionnaire containing sociodemographic details and questions on knowledge, attitude, and practice (KAP) regarding COVID-19 infection. Data were analyzed using SPSS version 20 software.

Results: A total of 288 students were included in the study, with a mean age of $21 \pm 1.4$. The male-to-female ratio was $2.75: 1$. Medical students showed adequate knowledge (81.6\%), attitude $(91.3 \%)$, and practice $(84.7 \%)$ towards the COVID-19 pandemic, respectively. The main symptoms of COVID-19 infection were known to at least $83 \%$ of the participants. The majority (85.4\%) were aware that there is no specific treatment for COVID-19 infection and $90 \%$ were aware of the main modes of the disease transmission. The majority (99\%) of the medical students believed that COVID-19 infection could be prevented through social distancing, wearing masks, and the practice of self-hygiene. About $75.6 \%$ believed that government measures for prevention are adequate. Steam inhalation, saline gargling, and consumption of vitamin C-rich foodstuffs were the main specific measures adopted. Older age and female gender were found to be associated with better knowledge.
\end{abstract}

Conclusion: Adequate KAP levels among medical students in this study are attributable to the current lockdown and the strict government measures to contain the infection.

Keywords: COVID-19, Knowledge, Attitude, Practice, Medical students, Central Kerala, India

\section{Background}

Coronavirus refers to a group of viruses that cause illness, mostly among mammals and birds. In humans, coronavirus can cause respiratory tract infections that can range from mild diseases to lethal forms. Mild forms include diseases like the common cold, whereas severe infection may occur in case of coronavirus diseases like severe acute respiratory syndrome (SARS), Middle East Respiratory Syndrome (MERS), and coronavirus disease 2019 (COVID - 19) [1]. COVID-19 is a new strain of coronavirus in Wuhan, located in the Hubei province of China, in late December 2019. Gradually, many new cases were reported from numerous countries all over the world. On 11th March 2020, the World Health Organization (WHO) declared COVID -19 infection as a pandemic [2].

*Correspondence: anukizhatil@gmail.com

${ }^{1}$ Department of Community Medicine, Sree Narayana Institute of Medical Sciences, Ernakulam, Kerala, India

Full list of author information is available at the end of the article
As of December 9th, 2020, India's ministry of health and family welfare confirmed the overall COVID-19 cases to be 967,03,770, including 3,83,866 active cases and 91,78,946 cured/recovered cases. The first confirmed case in India was reported on 30th January 2020 in Kerala [3]. In Kerala, as of December 7th, 2020, the overall COVID-19 cases had reached $967,03,770$, including 3,83,866 active cases and 91,78,946 recoveries, and 2411 deaths [4]. Currently, the coronavirus COVID-19 is affecting 218 countries and territories around the world. As of December 9th, 2020, the number of COVID-19 cases reached 68,751685 and 1566711 deaths [5]. COVID - 19 infection is a severe pandemic threatening our national infrastructure and economy. Our world was not prepared to face such a crisis [6]. However, knowledge and awareness regarding symptoms and mode of transmission of the disease and preventive measures, including basic hygiene principles and measures adopted in the public health crisis, have proven effective in preventing the epidemic's spread in a broader scale. 
In line with this trend, numerous articles have reinforced the literature relating to knowledge, attitude, and practice towards COVID-19 among various populations [7-16]. Most studies showed growing awareness and knowledge of the people about the COVID-19 infection. However, some population groups are still far from receiving the correct information regarding the worldwide adopted prevention and treatment measures.

Moreover, the wrong and misleading information generated negative attitudes toward government measures to curb the virus's spread. Therefore, focusing on assessing and improving healthcare providers' knowledge, including medical students, as future health professionals is of utmost importance. This study aimed to assess the knowledge, attitude, and practice regarding COVID-19 infection and its factors among medical students at a private medical college in central Kerala, India.

\section{Methods}

Study design and background

A web-based cross-sectional study recruiting universal sampling technique was conducted from April to May 2020. Medical students at Sree Narayana Institute of Medical Sciences (SNIMS), Chalakka, India, were invited to participate in this study. SNIMS is a private medical college located in the coastal belt of Ernakulam District of central Kerala. The medical curriculum consists of 4.5 years of medical course followed by one year of rotating internship. English is the teaching language used in this institution. A total of 421 undergraduate medical students were studying in this institution at the time of the survey.

\section{Inclusion and exclusion criteria}

Undergraduate students of 1st, 2nd, 3rd, and final year batches, both gender, Indian citizens who are willing to participate in the study were included. However, non-Indian students, 4th, and fifth medical classes, post-graduate students, teaching staff, and those who were unwilling to participate were excluded from the study.

\section{Sample size calculation}

According to an online survey in Mumbai in India [17], the sample size was calculated using the formula; $\mathrm{N}=4 \mathrm{pq} \div \mathrm{d} 2$. $\mathrm{P}=71.2 \%$ (proportion of medical students having adequate awareness regarding COVID-19 infection as per the Mumbai study), $q=100-p=28.8 \%$, and $d=5 \%$ (allowable error). The final sample size was calculated to be 274 after Adding a nonresponse rate of $20 \%$.

\section{Study tool}

The study tool used for data collection was a self-designed semi-structured questionnaire containing sociodemographic details and nine questions on knowledge, attitude, and practice regarding COVID-19 infection. Two experts and a pilot validated the questionnaire tested among 20 medical students (not included in the study). Cronbach's alpha was used to assess the reliability and was found to be 0.71 . The questionnaire was distributed among the students as google forms (in the English Language) with its link put in their WhatsApp group. The students were asked to answer the questionnaire and respond within two working days.
Dependent variable

Responses to KAP questions were given in the form of "Multiple Choice", "Multiple Response", and "Yes/No". At least seven questions in each section should be answered correctly to be considered an adequate knowledge, attitude, and practice level.

\section{Independent variables}

A10 $\mathrm{ml}$ of Actimera infusion may cost about IQD 2,250,000. Gender is recorded as "Male" and "Female". The religion of participants has been categorized into "Hindu", "Christian", "Muslim", and those with "No Religion (Others)". Marital status has been reported as "Married" and "Unmarried (single, widows, and divorced)". Respondents were categorized according to their family as "Nuclear Family" when the family consists of their parents and siblings only, and "Joint Family" when the family consists of several married couples and their children and men are all related by blood. The women are either their wives, unmarried girls, or widows of their family relatives. While the "Three Generation Family" when the family consists of parents, grandparents, and siblings only [18]. The socioeconomic status was classified into five categories based on the family's per capita monthly income and according to modified BG Prasad's classification for January 2020. When the income was above Indian Rupees (INR), 7533 is "an upperclass category". When the income was between INR 3766 and INR, 7532 is "an upper-middle-class category". When the income was between INR 2260 and INR 3765 is "a middleclass category". When the income was between INR 1130 and INR, 2259 it is "a lower-middle-class category". When the income was INR 1129 and below is" a lower-class category" [19]

\section{Statistical Analysis}

Collected data were entered in Microsoft Excel and were analyzed using SPSS version 20 software. Descriptive statistics were expressed in Mean ( \pm Standard Deviation), percentage and frequencies. In bivariate analysis, the Chi-Square test of significance was applied to test the association between various variables. Multivariate logistic regression analysis was used on factors significantly associated with adequate KAP levels. The p-value less than 0.05 was considered statistically significant.

\section{Results}

A total of 288 students were included in the study, with a mean age of $21.07 \pm 1.37$. Majority of respondents were males (211, $73.3 \%)$, Hindus $(206,71.5 \%)$, unmarried $(283,98.3 \%)$, from nuclear family $(243,84.4 \%)$ and at a lower-middle socioeconomic category $(203,70.5)$ (Table 1$)$

\section{Knowledge about COVID-19 infection}

The main symptoms of COVID-19 infection, i.e., fever, dry cough, and breathing difficulty, were correctly reported by $241(83.7 \%)$ respondents. More than half of students $(161,56 \%)$ defined the elderly above 60 years as the high-risk group for COVID-19 infection. However, 127 (44\%) believed that all age groups were equally susceptible to the infection. The results showed that $85.4 \%$ and $90.9 \%$ of the respondents were aware of no specific treatment or vaccine for COVID-19 infection, respectively. Nearly $90.0 \%$ of respondents have correct knowledge about the disease's main modes of transmission, and 92.7\% agreed that asymptomatic cases can still spread the infection (Table 2) 
Table 1 Sociodemographic variables $(\mathrm{N}=288)$

\begin{tabular}{lll}
\hline Variables & Category & $\mathbf{N}(\%)$ \\
\hline Sex & Male & $211(73.3)$ \\
Religion & Female & $77(26.7)$ \\
& Hindu & $206(71.5)$ \\
& Christian & $46(16)$ \\
& Muslim & $31(10.8)$ \\
Marital status & No Religion (Others) & $5(1.7)$ \\
\multirow{3}{*}{ Type of Family } & Unmarried & $283(98.3)$ \\
& Married & $5(1.7)$ \\
& Nuclear Family & $243(84.4)$ \\
Socioeconomic status & Joint Family & $22(7.6)$. \\
& Three generation family & $23(8.0)$ \\
& Upper & $12(4.2)$ \\
& Upper middle & $9(3.1)$ \\
& Middle & $20(6.9)$ \\
& Lower middle & $203(70.5)$ \\
& Lower & $44(15.3)$ \\
\hline
\end{tabular}

Table 2 Questions on Knowledge about COVID-19 (N = 288)

\begin{tabular}{|c|c|c|}
\hline Knowledge Questions & $\begin{array}{l}\text { Correct } \\
\text { response } \\
(\%) \\
\end{array}$ & $\begin{array}{l}\text { Wrong } \\
\text { response } \\
(\%)\end{array}$ \\
\hline Main symptoms of COVID-19? & $241(83.7 \%)$ & $47(16.3 \%)$ \\
\hline $\begin{array}{l}\text { Which age group is more } \\
\text { susceptible to COVID-19 } \\
\text { infection? }\end{array}$ & $161(56 \%)$ & $127(44 \%)$ \\
\hline Is there a vaccine for COVID-19? & $262(91 \%)$ & $26(9 \%)$ \\
\hline $\begin{array}{l}\text { How does coronavirus get } \\
\text { transmitted? }\end{array}$ & $258(90 \%)$ & $30(10 \%)$ \\
\hline $\begin{array}{l}\text { Can surgical masks be used in } \\
\text { hospital general wards and OPDs } \\
\text { as a preventive measure for } \\
\text { COVID-19 infection? }\end{array}$ & $234(81.3 \%)$ & $54(18.7 \%)$ \\
\hline $\begin{array}{l}\text { Does COVID-19 infection have } \\
\text { any specific treatment? }\end{array}$ & $246(85.4 \%)$ & $42(14.6 \%)$ \\
\hline $\begin{array}{l}\text { What happens to a person suffering } \\
\text { from COVID } 19 \text { infection? }\end{array}$ & $233(81 \%)$ & $55(19 \%)$ \\
\hline $\begin{array}{l}\text { How long is the quarantine period } \\
\text { for a suspected contact case of } \\
\text { COVID-19 infection recommended } \\
\text { by India's Government? }\end{array}$ & $213(74 \%)$ & $75(26 \%)$ \\
\hline $\begin{array}{l}\text { Can asymptomatic patients spread } \\
\text { COVID- } 19 \text { infection? }\end{array}$ & $267(92.7 \%)$ & $21(7.3 \%)$ \\
\hline
\end{tabular}

\section{Attitude towards COVID-19 infection}

The majority $(285,99 \%)$ of the medical students believed that infection could be prevented through social distancing, wearing masks, and by the practice of self-hygiene, and $287(99.7 \%)$ of them agreed on the necessity to follow the official updates about COVID-19 infection provided by the government, respectively. Most of the respondents (94.8\%) believed that the present lockdown has significantly reduced the number of cases. Moreover, most of the surveyed students (60.8\%) agreed that this infection would be finally successfully contained, and the Indian government's measures to prevent it are adequate $(75.7 \%)$. The study also found that $(80.0 \%)$ of the students expressed willingness to treat a COVID-19 patient if given an opportunity (Table 3).
Table 3 Questions on attitude towards COVID-19 ( $\mathrm{N}=288)$

\begin{tabular}{|c|c|c|}
\hline Attitude Questions & $\begin{array}{l}\text { Correct } \\
\text { response } \\
(\%)\end{array}$ & $\begin{array}{l}\text { Wrong } \\
\text { response } \\
(\%)\end{array}$ \\
\hline $\begin{array}{l}\text { If you or your close ones are having } \\
\text { coronavirus symptoms, what do you } \\
\text { think you should do? }\end{array}$ & $211(73.3 \%)$ & $77(26.7 \%)$ \\
\hline $\begin{array}{l}\text { Do you believe that you can prevent } \\
\text { yourself from being infected by } \\
\text { COVID-19 by practicing proper social } \\
\text { distancing, wearing masks, and self- } \\
\text { hygiene? }\end{array}$ & $\begin{array}{l}285 \\
(99.0 \%)\end{array}$ & $3(1.0 \%)$ \\
\hline $\begin{array}{l}\text { Will you avoid attending crowded } \\
\text { places or mass functions, even when } \\
\text { invited by close acquaintances? }\end{array}$ & $271(94.1 \%)$ & $17(5.9 \%)$ \\
\hline $\begin{array}{l}\text { Do you think it is necessary to follow } \\
\text { official updates about the Covid-19 } \\
\text { infection? }\end{array}$ & $287(99.7 \%)$ & $1(0.3 \%)$ \\
\hline $\begin{array}{l}\text { Do you think it is necessary to verify } \\
\text { the WhatsApp forward messages about } \\
\text { COVID-19 infection? }\end{array}$ & $242(84 \%)$ & $46(16 \%)$ \\
\hline $\begin{array}{l}\text { Are you ready to treat a COVID-19 } \\
\text { infected patient? }\end{array}$ & $232(80.6 \%)$ & $56(19.4 \%)$ \\
\hline $\begin{array}{l}\text { Do you agree that COVID-19 will be } \\
\text { successfully contained? }\end{array}$ & $175(60.8 \%)$ & $113(39.2 \%)$ \\
\hline $\begin{array}{l}\text { Do you think the government's } \\
\text { initiatives to prevent COVID-19 are } \\
\text { adequate? }\end{array}$ & $218(75.7 \%)$ & $70(24.3 \%)$ \\
\hline $\begin{array}{l}\text { Do you think this lockdown is helping } \\
\text { in reducing the number of cases? }\end{array}$ & $273(94.8 \%)$ & $15(5.2 \%)$ \\
\hline
\end{tabular}

\section{Practice regarding COVID-19 infection}

Nearly $99.0 \%$ of the medical students had a regular practice of wearing face masks while going out, and $93.4 \%$ of them used alcoholic hand rubs regularly. Moreover, most of them (96.5\%) had avoided a handshake since the current lockdown has started. Most of the surveyed students (97.0\%) followed preventive measures like covering the nose and mouth while sneezing/coughing. More than three-quarters (78.0\%) of respondents had a regular tracking of the disease trend. More than ninety percent of them do hand washing at least three times a day in which nearly $34.0 \%$ do it more than six times a day (Table 4)

Specific measures to prevent COVID-19 infection Table 5 presents the percentage of students practicing specific measures to prevent COVID-19 infection. About $33.0 \%$ of the students used steam inhalation, $26.7 \%$ used saline gargling, and $2.7 \%$ have applied oil in their noses as a preventive measure against COVID-19 infection. Regarding specific foodstuffs taken orally, $35.7 \%$ of students had consumed vitamin C-rich food, $25.0 \%$ had the habit of consuming spices like turmeric, jeera, etc., and $18.0 \%$ specifically consumed Vitamin D-rich foodstuffs, respectively. Ayurvedic medicines were consumed by $5.2 \%$ of the study participants as a preventive measure (Table 5). 
Table 4 Questions on practice towards COVID-19 (N = 288)

\begin{tabular}{|c|c|c|}
\hline Practice Questions & $\begin{array}{l}\text { Correct } \\
\text { response } \\
(\%)\end{array}$ & $\begin{array}{l}\text { Wrong } \\
\text { response } \\
(\%)\end{array}$ \\
\hline $\begin{array}{l}\text { Do you avoid handshaking in this time } \\
\text { of a pandemic? }\end{array}$ & $278(96.53 \%)$ & $10(3.47 \%)$ \\
\hline How often do you wash your hands? & $266(92.4 \%)$ & $22(7.6 \%)$ \\
\hline $\begin{array}{l}\text { Do you use hand sanitizer/alcoholic } \\
\text { hand rub? }\end{array}$ & $269(93.4 \%)$ & $19(6.6 \%)$ \\
\hline $\begin{array}{l}\text { Do you wear a face mask when you } \\
\text { go out to public places? }\end{array}$ & $285(98.96 \%)$ & $3(1.04 \%)$ \\
\hline $\begin{array}{l}\text { Do you cover your mouth and nose } \\
\text { while you sneeze and cough? }\end{array}$ & $280(97.2 \%)$ & $8(2.8 \%)$ \\
\hline $\begin{array}{l}\text { What will you do if you have or } \\
\text { suspected to have had contact with an } \\
\text { infected person? }\end{array}$ & $209(72.6 \%)$ & $79(27.4 \%)$ \\
\hline $\begin{array}{l}\text { Do you keep track of the trend the } \\
\text { disease is taking? }\end{array}$ & $225(78.13 \%)$ & $\begin{array}{l}63(21.87 \\
\%)\end{array}$ \\
\hline $\begin{array}{l}\text { Do you practice any of the following } \\
\text { to prevent COVID-19 infection (Table } \\
\text { 5) }\end{array}$ & $92(31.9 \%)$ & $\begin{array}{l}196(68.1 \\
\%)\end{array}$ \\
\hline $\begin{array}{l}\text { Do you consume any of the following } \\
\text { special food items to prevent COVID- } \\
19 \text { infection (Table 5) }\end{array}$ & $100(34.7 \%)$ & $\begin{array}{l}188(65.3 \\
\%)\end{array}$ \\
\hline
\end{tabular}

Table 5 Specific practices used against COVID-19 $(\mathrm{N}=288)$

\begin{tabular}{ll}
\hline Specific practices against infection & $\mathbf{N}(\%)$ \\
\hline Apply oil in the nose & $8(2.7)$ \\
Gargling with salt water & $77(26.7)$ \\
Steam inhalation & $95(32.9)$ \\
Oral consumption of specific items & \\
Ayurvedic medicines & $15(5.2)$ \\
Spices like Jeera, Turmeric, etc & $72(25)$ \\
Vitamin D rich foodstuffs & $52(18.1)$ \\
Vitamin C rich foodstuffs & $103(35.7)$ \\
Tulasi & $1(0.3)$ \\
Mutton Soup for immunity & $1(0.3)$ \\
\hline
\end{tabular}

Overall, $81.6 \%, 91.3 \%$, and $84.7 \%$ of the surveyed medical students showed adequate knowledge, attitude, and practice towards the COVID-19 pandemic, respectively. A good practice towards COVID-19 prevention was found to have a statistically significant association with adequate knowledge about the COVID-19 pandemic ( $\mathrm{P}=0.038$ ) (Table 6). Additionally, increasing age and female gender were found to have a statistically significant association with adequate KAP regarding COVID-19 infection among the sociodemographic variables. On Multivariate logistic regression analysis female gender was found to have significantly higher KAP levels than the counterparts (Adjusted Odds ratio: 2.2, 95\% Confidence interval: $1.2-4.2$, p-value 0.013) (data did not show in tables).

\section{Discussion}

In this study, medical students scored $81.6 \%, 91.3 \%$, and $84.7 \%$ correct rate of knowledge about, attitude towards, and practice for the COVID-19 pandemic. Medical students have sufficient coronavirus knowledge, reflecting the benefits of the extensive health education they may get through television, radio, internet, mobile phone messages, discussion among peer groups, etc., added to their medical knowledge and involvement in public health campaigns. Moreover, adequate knowledge positively influenced the attitude and practice of surveyed students towards COVID 19, as shown in table 6. Similar findings were reported in previous studies conducted in different regions among different populations worldwide [7-20]. An Indian study conducted by Maheswari et al. [7] among medical students in Uttarakhand found that $92.7 \%$ of the participants had extensive knowledge of COVID-19 infection, and more than $80.0 \%$ had a positive attitude towards COVID19. Tahrir and his colleagues [8], in their study among Iranian medical students, indicated that on average, about $86.96 \%$ had a correct answer of knowledge, and $94.47 \%$ had an average rate of performance in preventive behaviors.

Moreover, Peng et al. [9] reported that Chinese medical students had good knowledge $(83.0 \%)$, a positive attitude $(75.8 \%)$, and proactive practice $(87.9 \%)$, respectively. Alzoubi et al. [10] surveyed medical and non-medical students in Jordan. The author found that $90.0 \%$ of the participants had good knowledge about symptoms of COVID-19, and more than $80.0 \%$ were aware of the lack of vaccine and treatment for COVID-19. Likewise, about $80.0 \%-90.0 \%$ of our participants knew that fever, cough, breathing difficulty are the main symptoms of COVID-19 infection. Moreover, they know the transmission modes, and there is no specific antiviral treatment or vaccine against COVID- 19 .

Table 6 Association between adequate practice and attitude with adequate knowledge $(\mathrm{N}=288)$

\begin{tabular}{llll}
\hline \multicolumn{3}{c}{ Knowledge level } & P-value \\
\hline & $\begin{array}{l}\text { Adequate } \\
\text { Knowledge }\end{array}$ & $\begin{array}{l}\text { Inadequate } \\
\text { Knowledge }\end{array}$ & \\
$\begin{array}{l}\text { Attitude level } \\
\text { Adequate }\end{array}$ & $218(75.7 \%)$ & $70(24.3 \%)$ & 0.066 \\
$\begin{array}{l}\text { Inadequate } \\
\text { Practice level }\end{array}$ & $17(68 \%)$ & $8(32 \%)$ & \\
$\begin{array}{l}\text { Adequate } \\
\text { Inadequate }\end{array}$ & $204(83.6 \%)$ & $40(16.4 \%)$ & $0.038^{*}$ \\
\hline
\end{tabular}

Additionally, about sixty percent of participants were confident that COVID-19 could be successfully controlled, and $76.0 \%$ of them believed that the government measures, including the lockdown (95.0\%), would reduce the number of cases. Consequently, the Indian government can win the battle against COVID-19. Our results are consistent with other findings from India [7], Iraq [11], Pakistan [12], Turkey [13], Saudi Arabia [14], China [15], and Nepal [16]. The highest percent (99.0\%) of medical students agreed that preventive measures such as social distancing, wearing masks, and practicing self-hygiene contribute to preventing the epidemic's spread. Therefore, most of them are wearing face masks while going out, using alcoholic hand rubs, avoiding a handshake, and covering nose and mouth while sneezing or coughing. We believe that the compliance in accepting the preventive practices implemented by the Indian government is attributable to the strict lockdown and good knowledge. Good practice has a statistically significant association with good knowledge; still, about $18.4 \%$ of students have inadequate knowledge. Therefore, $5.0 \%$ of them refrained from covering their mouth and nose while 
coughing and sneezing. Similarly, about $4.5 \%$ of Nepalese with medical degrees visited crowded places, $6.5 \%$ refused to wear masks when leaving homes, and $4.4 \%$ abstained from washing hands according to WHO guidelines [16]. Indeed, at the first invasion of COVID-19, most of the residents all over the world displayed promising practices such as avoiding crowded places and wearing masks when leaving home, handwashing, refraining from shaking hands, and following the etiquette of coughing and sneezing [7-16]. In terms of sociodemographic variables, males showed lower KAP levels compared to females. Our results are consistent with the study done by Peng et al.[9] which reported that females had a significantly higher score than males, and the result was statistically significant.

We found our results encouraging since good hygiene practices, behavioral commitment, and social distancing aids in decreasing the transmission rate of COVID-19. These results are comparable with a study performed in China, where the vast majority of the participants held an optimistic attitude towards the COVID-19 epidemic[9] and other studies, where the participants generally revealed adequate positive practices towards the COVID-19 disease[ 9-14]. Moreover, about 80.0\% of the surveyed students were willing to treat a COVID-19 patient if given an opportunity. The study's limitation was the data collection from a single medical college through an online survey, which is considered to have a poor response rate. Hence, the study results cannot be generalized. The data also was collected using a self-reported questionnaire, which can be a potential cause of reporting bias.

\section{Conclusion}

Our study found out that knowledge, attitude, and practice levels of the majority $(81.6 \%, 91.3 \%$, and $84.7 \%$, respectively) of medical students regarding COVID 19 infection were above the adequate levels. Sociodemographic factors like age and gender also significantly influenced the KAP levels. The lockdown, government measures to contain the infection, and the general awareness regarding medical issues among the medicos have played a vital role in improving the students' KAP levels and hence in preventing the infection. Such KAP studies on COVID 19 infection should be conducted across other medical colleges to substantiate our study findings. Studies should also be conducted among other nonmedical undergraduates and the general population to identify low KAP levels. Health promotional activities, including health education sessions, should be organized in such populations through universities, local government bodies, and non-governmental organizations, which will go a long way in containing the epidemic.

\section{Abbreviation}

COVID-19: Coronavirus disease 2019; SARS: Severe Acute Respiratory Syndrome; MERS: Middle East Respiratory Syndrome; KAP: Knowledge, Attitude, Practice; INR: Indian Rupees

\section{Declaration \\ Acknowledgment \\ None.}

\section{Funding}

The authors received no financial support for their research, authorship, and/or publication of this article.
Availability of data and materials

Data will be available by emailing anukizhatil@gmail.com.

\section{Authors' contributions}

Jacob Davies Kalliath (JDK) conceptualized the study, did a literature review, designed a survey, defined intellectual content, drafted the manuscript, reviewed, and edited. Anuradha Kizhatil (AK) defined intellectual content, designed survey, performed survey, assisted manuscript preparation, reviewed, and edited. Billy M Rose (BRM) made data acquisition, data analysis, statistical analysis, and interpreted data; Ann Mary Thomas (AMT) drafted the manuscript and improved data interpretation. Alexander John (AJ) critically reviewed and revised the manuscript. All authors substantially contributed to the study and approved its submission.

\section{Ethics approval and consent to participate}

We conducted the research following the Declaration of Helsinki. Ethical approval was obtained from the institutional ethics committee (Sree Narayana Institute of Medical Sciences IEC/30/02, April 2020). Informed consent was also obtained from students before data collection through WhatsApp messages. Anonymity was maintained in the questionnaire as well.

Consent for publication

Not applicable

\section{Competing interest}

The authors declare that they have no competing interests.

\section{Open Access}

This article is distributed under the terms of the Creative Commons $\begin{array}{llll}\text { Attribution } & 4.0 & \text { International License }\end{array}$ (http://creativecommons.org/licenses/by/4.0/), which permits unrestricted use, distribution, and reproduction in any medium, provided you give appropriate credit to the original author(s) and the source, provide a link to the Creative Commons license, and indicate if changes were made. The Creative Commons Public Domain Dedication waiver (http://creativecommons.org/publicdomain/zero/1.0/) applies to the data made available in this article, unless otherwise stated.

Author Details

${ }^{1}$ Department of Community Medicine, Sree Narayana Institute of Medical Sciences, Ernakulam, Kerala, India

Article Info

Received: 21 January 2020

Accepted: 01 April 2020

Published: 14 April 2021

\section{References}

1. World Health Organization. Available from: https://www.WHO.int/dg/speeches/detail/who-directorgeneralsopeningremarks-at-the-media-briefing-on-Covid-19 [Accessed on 21st April 2020].

2. World Health Organization, WHO Director-General's opening remarks at the media briefing on COVID-19 -11 March 2020. Available from: https://www.who.int/directorgeneral/speeches/detail/who-director-general-s-opening-remarks- 
at-the-media-briefing-on-covid-19---11-march-2020 [Accessed on 21st April 2020].

3. Ministry of Health and Family Welfare Government of IndiaCovid-19, India. Available from: https://www.mohfw.gov.in/ [Accessed on 21st April 2020].

4. GoK dashboard-Kerala: Covid-19 Battle. Available from: https://dashboard.kerala.gov.in/. [Accessed on 9th December 2020].

5. Worldometer-Covid-19 Coronavirus pandemic. Available from: https://www.worldometers.info/coronavirus/ [Accessed on 9th December 2020].

6. Ali Jadoo SA. Was the world ready to face a crisis like COVID19? Journal of Ideas in Health2020;3(1):123-4. https://doi.org/10.47108/jidhealth.Vol3.Iss1.45

7. Maheshwari S, Gupta P, Sinha R, Rawat P. Knowledge, attitude, and practice towards coronavirus disease 2019 (COVID-19) among medical students: A cross-sectional study. J Acute Dis. 2020;9(3):100-4. https://doi.org/10.4103/2221-6189.283886)

8. Tahrir MH, Borazjani R, Shirley R. COVID-19 and Iranian medical students; a survey on their related-knowledge, preventive behaviors and risk perception. Arch Iran Med. 2020;23(4):249254. https://doi.org/10.34172/aim.2020.06)

9. Peng Y, Pei C, Zheng Y, Wang J, Zhang K, Zheng Z, Zhu P. Knowledge, attitude and practice associated with COVID-19 among university students: a cross sectional study in China. BMC Public Health 2020; 1292. https://doi.org/10.1186/s12889-02009392-z

10. Alzoubi H, Alnawaiseh N, Lubad MA, Aqel A, Al-Shagahin H. COVID-19 - knowledge, attitude and practice among medical and nonmedical university students in Jordan. J Pure Appl Microbiol. 2020;14(1):17-24. https://doi.org/10.3389/fpubh.2020.00253

11. Ali Jadoo SA, Alhusseiny A, Yaseen S, Al-Samarrai M, Al-Rawi R, Al-Delaimy A, Abed M, Hassooni H. Knowledge, attitude, and practice toward COVID-19 among Iraqi people: a web-based cross-sectional study. Journal of Ideas in Health 2020; 3(Special2):258-65.

https://doi.org/10.47108/jidhealth.Vol3.IssSpecial\%202.59
12. Noreen K, Rubab Z, Umar M, Rehman R, Baig M, Baig F. Knowledge, attitudes, and practices against the growing threat of COVID-19 among medical students of Pakistan. Plos One. 2020;15(12): e0243696. https://doi.org/10.1371/journal.pone.0243696)

13. Ali Jadoo SA, Dastan I, Al-Samarrai M, Yaseen S, Abbasi A, Alkhdar H, Al-Saad M, Danfour O. Knowledge, attitude, and practice towards COVID-19 among Syrian people resident in Turkey. Journal of Ideas in Health 2020; 3(Special2):278-85. https://doi.org/10.47108/jidhealth.Vol3.IssSpecial2.61

14. Al-Hanawi MK, Angawi K, Alshareef N, Qattan AMN, Helmy HZ, Abudawood Y, Alqurashi M, Kattan WM, Kadasah NA, Chirwa GC, Alsharqi O. Knowledge, attitude and practice toward COVID-19 among the public in the kingdom of Saudi Arabia: a cross-sectional study. Front Public Health. 2020; 8:217. https://doi.org/10.3389/fpubh.2020.00217

15. Zhong BL, Luo W, Li HM, Zhang QQ, Liu XG, Li WT, et al. knowledge, attitudes, and practices towards COVID-19 among Chinese residents during the rapid rise period of the COVID-19 outbreak: A quick online cross-sectional survey. Int J Biol Sci. 2020;16(10):1745-52. https://doi.org/10.7150/ijbs.45221

16. Asraf H, Garima T, Singh BM, Ram R, Tripti RP. Knowledge, attitudes, and practices towards COVID-19 among Nepalese Residents: A quick online cross-sectional survey. Asian Journal of Medical Sciences. 2020;11(3):6-11. https://doi.org/10.3126/ajms.v11i3.28485

17. Modi P D, Nair G, Upper A, Modi J, Tuppekar B, Gharpure AS, et al. COVID-19 Awareness Among Healthcare Students and Professionals in Mumbai Metropolitan Region: A QuestionnaireBased Survey. Cureus. 2020;12(4): e7514. https://doi.org/10.7759/cureus.7514

18. Park K. Park's Textbook of Preventive Medicine. 25th edition. Jabalpur: m/s Banarsidas Bhanot; 2019.p.740.

19. Debnath DJ, Kakkar R. Modified BG Prasad Socio-economic Classification Updated - 2020. Indian J Comm Health.2020;32(1):124-125. 